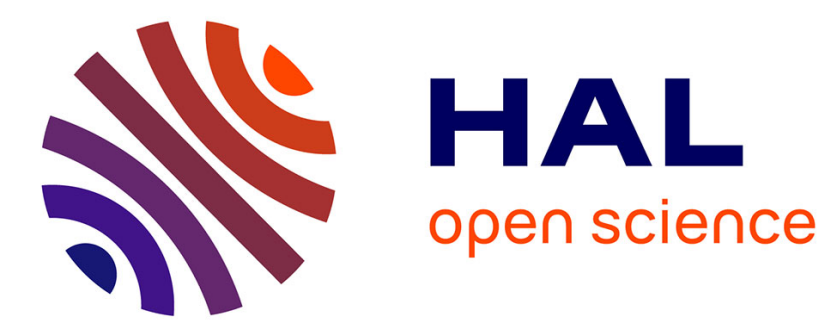

\title{
Root development of non-accumulating and hyperaccumulating plants in metal contaminated soils amended with biochar
}

Frédéric Rees, Thibault Sterckeman, Jean-Louis Morel

\section{- To cite this version:}

Frédéric Rees, Thibault Sterckeman, Jean-Louis Morel. Root development of non-accumulating and hyperaccumulating plants in metal contaminated soils amended with biochar. 8. 20th World Congress of Soil Science, Jun 2014, Jeju, North Korea. 2014. hal-02794196

\section{HAL Id: hal-02794196 \\ https: / hal.inrae.fr/hal-02794196}

Submitted on 5 Jun 2020

HAL is a multi-disciplinary open access archive for the deposit and dissemination of scientific research documents, whether they are published or not. The documents may come from teaching and research institutions in France or abroad, or from public or private research centers.
L'archive ouverte pluridisciplinaire HAL, est destinée au dépôt et à la diffusion de documents scientifiques de niveau recherche, publiés ou non, émanant des établissements d'enseignement et de recherche français ou étrangers, des laboratoires publics ou privés. 
(U) UNIVERSITÉ

\section{ROOT DEVELOPMENT IN METAL CONTAMINATED SOILS AMENDED WITH BIOCHAR}

Frédéric REES ${ }^{1}$, Thibault STERCKEMAN'1, Jean-Louis MOREL

"corresponding author: Frédéric REES, fireesogisfi.fr
1 Université de Lorraine/INRA, Laboratoire Sols et Environnement F-54500 Vandœurre-lès-Nancy, France

\section{INTRODUCTION}

Biochar, the solid product from biomass pyrolysis used as soil amendment, has emerged as a promising carbon sink and soi improver. Its sorbent properties could also be used in the remediation of contaminated soils, particularly in phytoremediation.

Biochar's influence on root growth is however poorly known [1], e.g. for soils contaminated with heavy metals. An increase of root surface in those soils may lead to a decrease of metal leaching, as less water is percolating, but also to an increase of metal uptake by the plant, as the exchange surface between soil and plant is increasing.
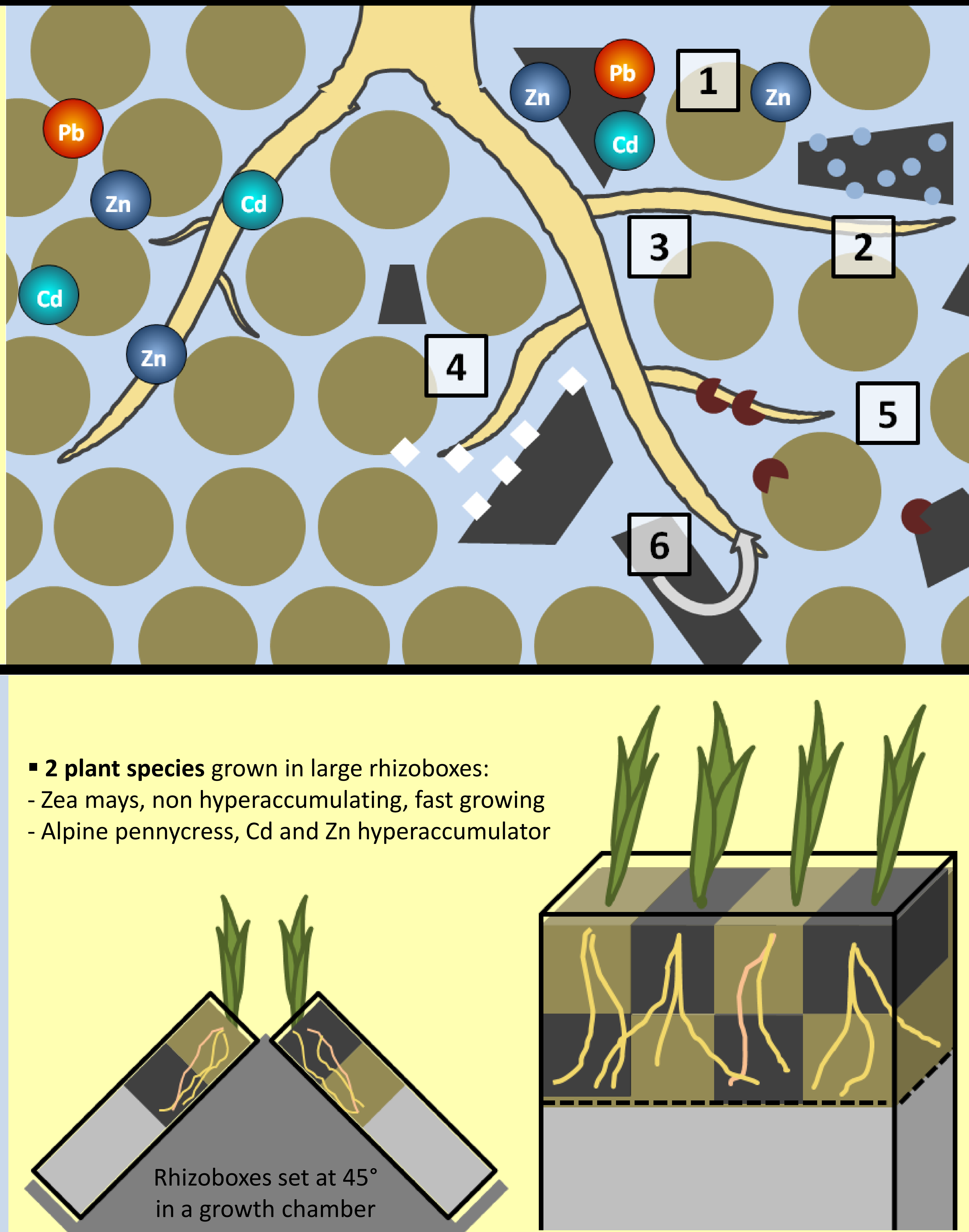

- 2 plant species grown in large rhizoboxes: Zea mays, non hyperaccumulating, fast growing
In this context, several mechanisms could explain a better root development:

[1] Soil toxicity $\searrow$

[2] Water availability $\nearrow$

[3] Resistance to root penetration $\searrow$

[4] Nutrient availability $\lambda$

[5] Beneficial microorganisms are promoted

[6] Biochar induces plant hormonal response

$\rightarrow$ A rhizobox experiment was designed to:

1) Quantify the effect of biochar on root growth in contaminated soils

2) Identify a possible root tropism towards biochar, thanks to a specific design

\section{MATERIALS}

- 1 biochar produced by Carbon Terra at $\sim 450^{\circ} \mathrm{C}$ from woody biomass, $<2 \mathrm{~mm}$, untreated ( $\mathrm{pH} 9.2)$

- 2 soils contaminated with $\mathrm{Cd}, \mathrm{Zn}, \mathrm{Pb}$, sampled near smelters, with similar properties but different $\mathrm{pH}$.

$\mathrm{pH}$ value and available $\left(/\right.$ total) metals of soils $\left(\mathrm{mg} \mathrm{kg}^{-1}\right.$

\begin{tabular}{|c|c|c|c|c|}
\hline Soil & $p H$ & $\mathrm{Cd}$ & $\mathrm{Pb}$ & $\mathrm{Zn}$ \\
\hline Soil A & 5.9 & $\begin{array}{c}5.9 \\
/ 17.6\end{array}$ & $\begin{array}{c}1.7 \\
/ 1120\end{array}$ & $\begin{array}{c}\mathbf{6 8 4} \\
/ 3170 \\
\end{array}$ \\
\hline Soil B & 8.1 & $\begin{array}{c}\mathbf{0 . 2 4} \\
/ 18.6\end{array}$ & $\begin{array}{c}0.06 \\
/ 1080\end{array}$ & $\begin{array}{c}2.0 \\
/ 1380\end{array}$ \\
\hline
\end{tabular}

$\rightarrow$ With biochar, metal availability strongly $\searrow$ on Soil $A$ but only slightly on Soil B due to its higher initial $\mathrm{pH}^{[4]}$

\section{METHODS}

- 4 seedlings grown per rhizobox with $2000 \mathrm{~g}$ of soil, divided in 8 compartments as a chessboard:

\section{4 squares with pure soil}

4 squares with soil $+5 \%(w / w)$ biochar

- 2 rhizoboxes for each plant and soil

- Daily watering at $85 \%$ of water holding capacity

- High-resolution scanning of the soil profile

- After harvest ( 2 weeks for maize, 9 weeks for alpine pennycress):

$\rightarrow$ Recovery of roots and measurement of root surface with Winrhizo software
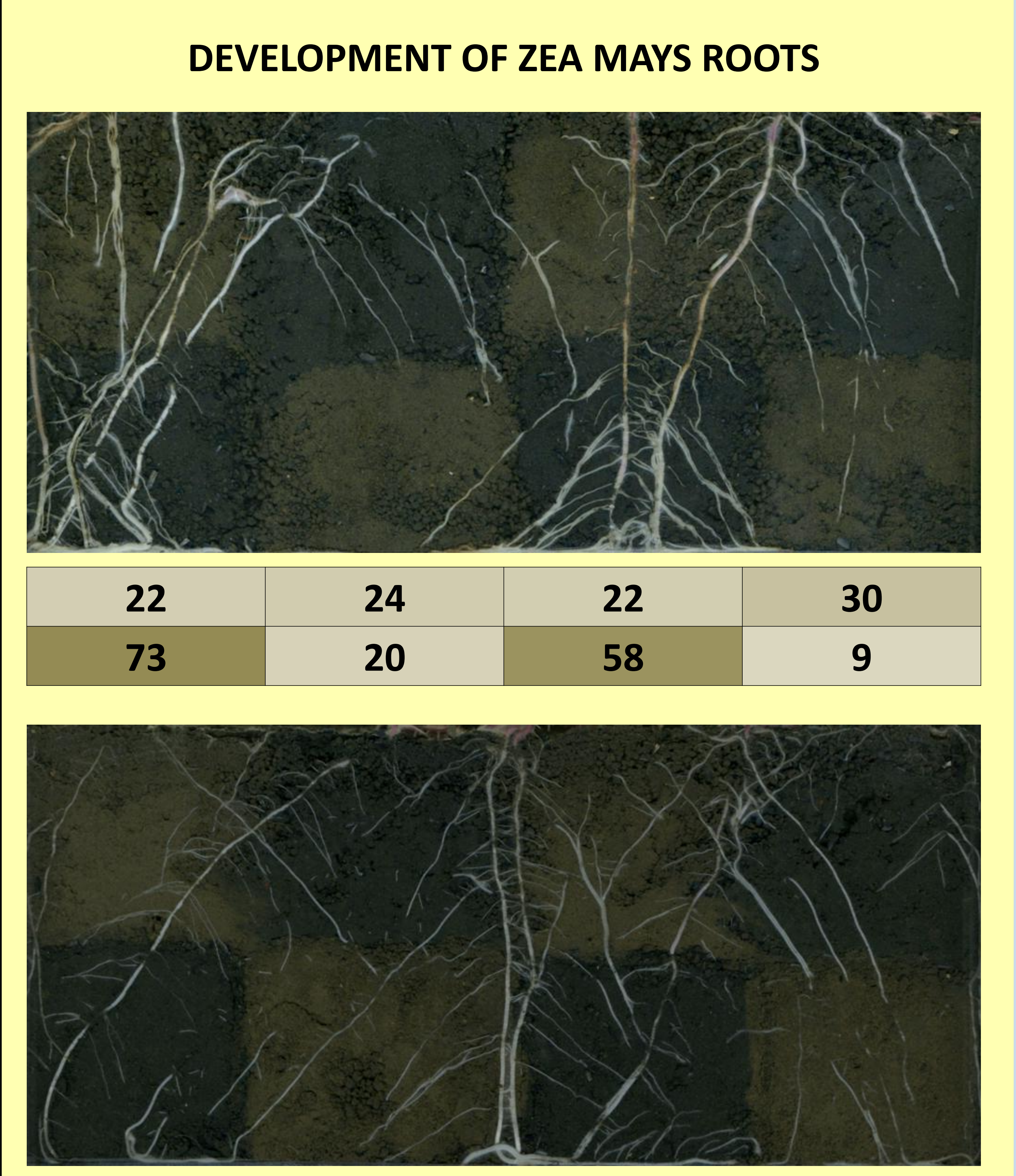

\begin{tabular}{|l|l|l|l|}
\hline 46 & 38 & 37 & 45 \\
\hline 50 & 34 & 46 & 53 \\
\hline
\end{tabular}

High-resolution pictures of soil profiles have been taken just after the harvest

\section{CONCLUSIONS}

- Considering that both soils have similar properties except $\mathrm{pH}$, the better root development with biochar only observed on Soil $A$ may be mainly due to the decrease of soil metal availability.

$\rightarrow$ Modifications of root development only occurs when biochar has a significant effect on chemical soil properties.
RESULTS \& DISCUSSION

ON SOIL A $\Rightarrow$

- The zones with biochar have a higher density of roots

- Roots are generally moving towards the zones with biochar $\rightarrow$ root tropism

$\Rightarrow$ Biochar has clear positive effects on root development in a soil with initial high metal availability and low $\mathrm{pH}$

\section{ON SOIL B}

- The zones with biochar do not have a higher density of roots

- No obvious trend of root tropism towards biochar can be observed

$\Rightarrow$ Biochar has no significant effects on root development in a soil with initial low metal availability and high pH

DEVELOPMENT OF ALPINE PENNYCRESS ROOTS
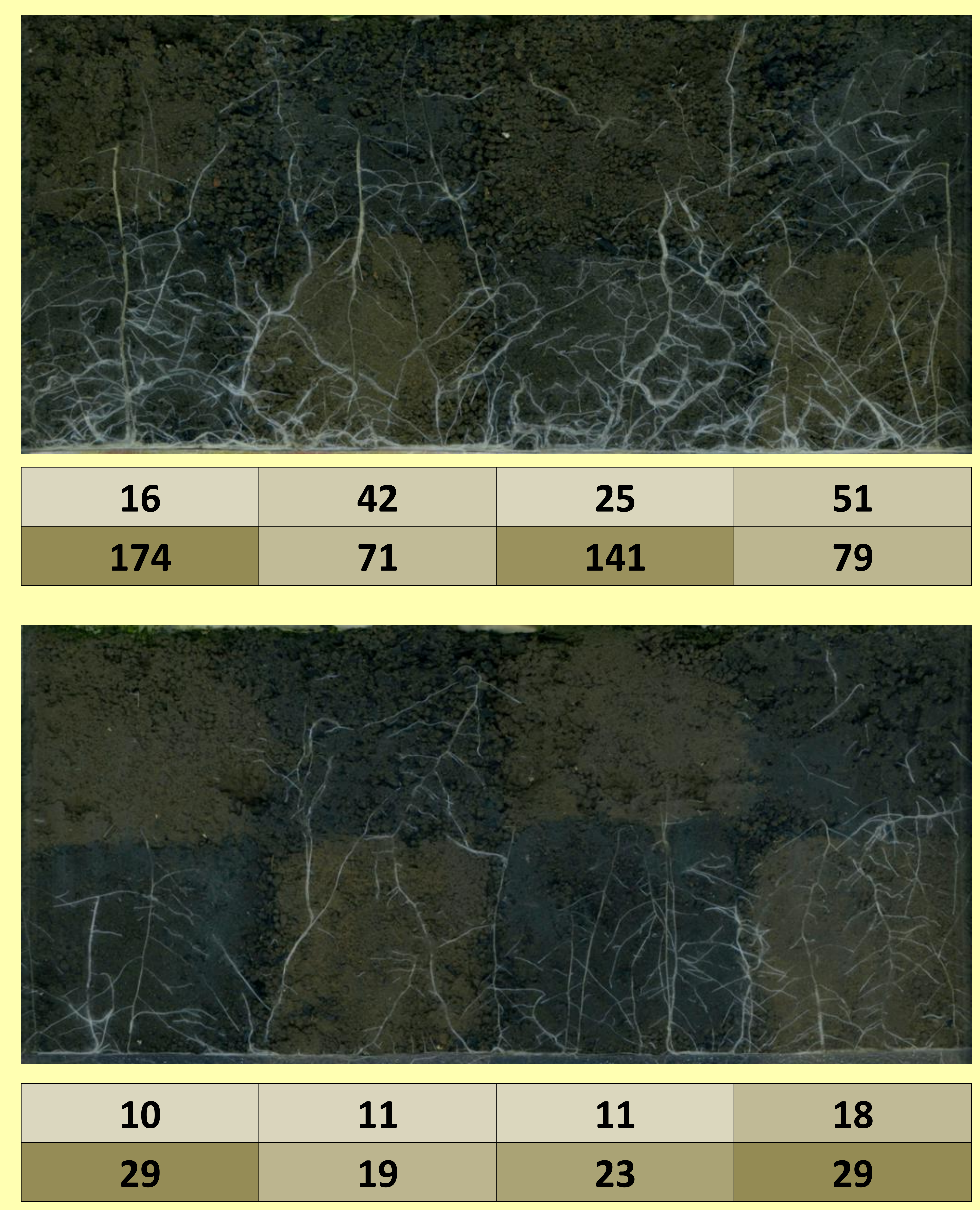

Tables represent the total root surface for the 8 squares of each soil profile (in $\mathrm{cm}^{2}$ )

\section{PERSPECTIVES}

- Positive tropism of roots - The consequences of a towards biochar could be an better root development on option to reduce the quantity of plant metal uptake and long biochar and the work for term growth need further biochar amendment. investigations. 